\title{
KENTUCKY GROUND-WATER QUALITY
}

By James L. Kiesler, Lloyd H. Woosley, Jr., and Robert W. Davis

U.S. Geological Survey Open-File Report 87-0727 


\section{DEPARTMENT OF THE INTERIOR \\ DONALD PAUL HODEL, Secretary}

\section{U.S. GEOLOGICAL SURVEY}

Dallas L. Peck, Director

For additional information:

Chief Hydrologist

U.S. Geological Survey

407 National Center

Reston, VA 22092
For sale by:

U.S. Geological Survey

Books and Open-File Reports Section Federal Center

Box 25425

Denver, Colorado 80225

Use of trade names in this report is for descriptive purposes only and does not constitute endorsement by the U.S. Geological Survey 


\section{FOREWORD}

This report contains summary information on ground-water quality in one of the 50 States, Puerto Rico, the Virgin Islands, or the Trust Territories of the Pacific Islands, Saipan, Guam, and American Samoa. The material is extracted from the manuscript of the 1986 National Water Summary, and with the exception of the illustrations, which will be reproduced in multi-color in the 1986 National Water Summary, the format and content of this report is identical to the State ground-water-quality descriptions to be published in the 1986 National Water Summary. Release of this information before formal publication in the 1986 National Water Summary permits the earliest access by the public. 


\section{Contents}

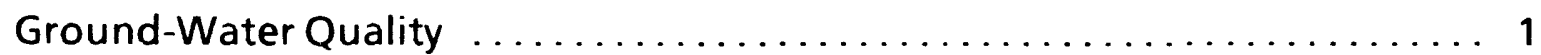

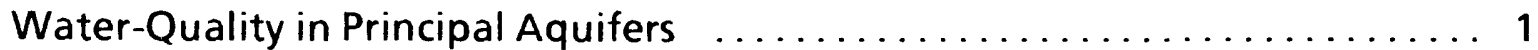

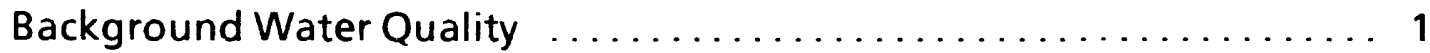

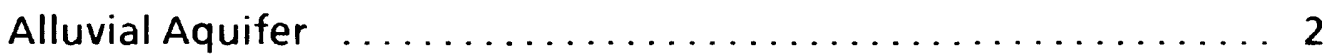

Tertiary and Cretaceous Aquifers $\ldots \ldots \ldots \ldots \ldots \ldots \ldots \ldots \ldots \ldots \ldots$

Pennsylvanian Aquifer System $\ldots \ldots \ldots \ldots \ldots \ldots \ldots \ldots \ldots \ldots$

Mississippian Aquifer System $\ldots \ldots \ldots \ldots \ldots \ldots \ldots \ldots \ldots \ldots \ldots$

Ordovician Aquifer System $\ldots \ldots \ldots \ldots \ldots \ldots \ldots \ldots \ldots \ldots \ldots$

Effects of Land Use on Water Quality $\ldots \ldots \ldots \ldots \ldots \ldots \ldots \ldots$

Waste Management and Chemical Storage .............. 3

Mineral Development ........................... 3

Urbanization ................................... 3

Potential for Water-Quality Changes $\ldots \ldots \ldots \ldots \ldots \ldots \ldots \ldots \ldots$

Ground-Water-Quality Management ...................... 4

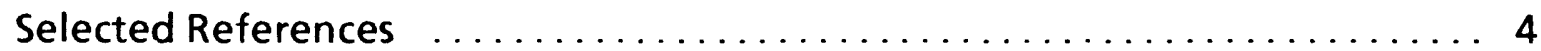

Illustrations

Figure 1.--Selected geographic feature and 1985 population distribution in

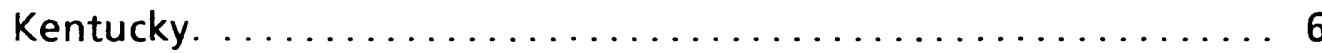

Figure 2.--Principal aquifers and related water-quality data in Kentucky.

Figure 3.--Selected waste sites and ground-water quality information in Kentucky.

Figure 4.--Fluctuations in ground-water quality and water level in the alluvial aquifer at Louisville. 


\section{Kentuaky Ground-Water Quality}

In the Commonwealth of Kentucky (fig. $1 A$ ) ground water supplies 22 percent of the total water withdrawn for all uses excluding thermoelectric power. About 31 percent of the total population is served by ground water (U.S. Geological Survey, 1985, p. 223). In the extensive karst areas of central Kentucky and in the coal-mining regions of the Commonwealth, ground water is the primary source of drinking water. The more densely populated urban areas (fig. 1B) are not as dependent upon ground water for drinking water because of the general availability of reliable surface water.

Generally, a thin veneer of freshwater in shallow aquifers overlies deep reservoirs that contain brackish water or brine at varying depths. Most shallow ground water is relatively unmineralized. Concentrations of dissolved solids, nitrate, and chloride in ground water generally are small, but iron concentrations in water from some shallow aquifers exceed the recommended standards for public water supplies. Also, water from some shallow aquifers is hard to very hard (fig. 2).

Locally, human activities have degraded the natural quality of ground water; the extent of this degradation is unknown. There are, however, several known and potential sources of ground-water contamination in Kentucky (fig. 3). Parts of the karstified limestone aquifers, which underlie about 50 percent of the Commonwealth, are contaminated; the contaminants are derived from both point and nonpoint sources. In karst topography, contaminated surface flows can enter the ground-water system directly through open sinkholes and solution openings. Such features make these aquifers very vulnerable to contamination. Septic systems that are improperly sited, designed, constructed, or maintained have been identified by the Kentucky Natural Resources and Environmental Protection Cabinet (1986, p. 50) as the most significant source of ground-water contamination statewide.

As of February 1987, there were 29 hazardous-waste management facilities in Kentucky that use a land unit for storage, treatment, or disposal of hazardous waste (Lori Johnson, Kentucky Natural Resources and Environmental Protection Cabinet, oral commun., 1987). The operators of these facilities are required to monitor ground-water quality under the Resource Conservation and Recovery Act (RCRA). However, "no contamination of drinking water wells or supplies by a hazardous waste facility has been documented to date' (Kentucky Natural Resources and Environmental Protection Cabinet, 1986, p. 83). An additional nine abandoned toxic-waste sites are listed on the National Priorities List (NPL), and the State has proposed the inclusion of one additional site (U.S. Environmental Protection Agency, 1986c). These sites require additional evaluation as part of the Comprehensive Environmental Response, Compensation, and Liability Act (CERCLA), commonly referred to as "Superfund." Ground-water contamination has been reported at 12 RCRA sites and 4 CERCLA sites.

Other known or potential sources of ground-water degradation in Kentucky include agricultural activities, underground storage tanks, municipal and radiological-waste landfills, and surface impoundments (Kentucky Natural Resources and Environmental Protection Cabinet, 1986). Also, coal mining and brine disposal by the oil and gas industry may be affecting extensive areas of the ground-water resource in south-central Kentucky and in the coal fields of eastern and western Kentucky. In addition, the effects of urbanization on ground-water quality have not been adequately defined. Isolated contamination incidents have been associated with pesticides and other organics, metals, radionuclides, chloride, fluoride, and nitrate.

\section{WATER QUALITY IN PRINCIPAL AQUIFERS}

Kentucky has five principal aquifers-the alluvial aquifer, the Tertiary and Cretaceous aquifers, the Pennsylvanian aquifer system, the Mississippian aquifer system, and the Ordovician aquifer system (figs. $2 A, B$ ). The aquifer types are unconsolidated sand and gravel in the alluvial aquifer along the Ohio, the Mississippi, and the downstream parts of the Cumberland and Tennessee Rivers; unconsolidated sand of the Tertiary and Cretaceous aquifers in extreme western Kentucky; fractured sandstone in the Pennsylvanian aquifer system in the eastern and western coal fields; and solution openings and fractures in the limestone in the Mississippian and the Ordovician aquifer systems in the north-central part of the Commonwealth. Of the State's total ground-water withdrawals, 63 percent is from the alluvial aquifer and the remaining 37 percent is withdrawn about equally from the other four aquifers (U.S. Geological Survey, 1985, p. 224).

Ground water generally is fresh-less than $1,000 \mathrm{mg} / \mathrm{L}$ (milligrams per liter) of dissolved solids-near the outcrop of the rocks that form the aquifers. However, the depth of the freshwater zone ranges from 25 to 2,000 feet below the land surface (Sprinkle and others, 1983, p. 13). The freshest ground water in Kentucky occurs in the Tertiary and Cretaceous aquifers; dissolved-solids concentrations in water from these aquifers generally are smaller than $170 \mathrm{mg} / \mathrm{L}$. Water from the alluvium, Mississippian, and eastern Kentucky Pennsylvanian aquifer systems is fresh. Water from the western Kentucky Pennsylvanian aquifers and the Ordovician aquifer system have median dissolved-solids concentrations of 551 and 516 $\mathrm{mg} / \mathrm{L}$, respectively. Although water from the western Kentucky Pennsylvanian sandstone and Ordovician limestone aquifers generally is fresh, the chance of obtaining slightly saline water ( 1,000 to $3,000 \mathrm{mg} / \mathrm{L}$ dissolved solids) from these aquifers is greater than elsewhere in the State.

Concentrations of nitrate (as nitrogen) across Kentucky generally do not exceed the $10 \mathrm{mg} / \mathrm{L}$ national primary drinkingwater standard. Nitrate data indicate that the largest concentrations are in the Mississippian and Ordovician aquifer systems, with median concentrations of 0.7 and $1.1 \mathrm{mg} / \mathrm{L}$, respectively. The geographical area comprising these aquifers contains most of the metropolitan Louisville area, all the Lexington, Frankfort, Bowling Green, Somerset, and Hopkinsville metropolitan areas, and many other smaller, densely populated areas.

\section{BACKGROUND WATER QUALITY}

Samples of ground water have been collected in Kentucky since the 1930's. The U.S. Geological Survey maintained a network of wells and springs from 1967 to 1982 and most of the samples were collected from that network. Samples collected as part of this network were analyzed for several variables including common ions, nitrate, $\mathrm{pH}$, and dissolved solids.

As the Commonwealth implements its ground-water protection strategy and continues to respond to incidents of contamination, data collected by the Kentucky Natural Resources and Environmental Protection Cabinet, U.S. Environmental Protection Agency, U.S. Geological Survey, and Kentucky Geological Survey, local governments, and facility operators will be added to the data base. These data will be used to document and analyze the effects of contamination incidents. Also, limited chemical data collected at public and private ground-water supply wells and springs, before the water is stored or treated, will be added to the data base. Groundwater-quality data for Kentucky were compiled by Faust and others 
(1980), and evaluated by Sprinkle and others (1983). The range of ground-water quality in Kentucky is illustrated by the graphical summary for dissolved solids, hardness (as calcium carbonate), nitrate (as nitrogen), chloride, and iron in figure $2 C$. Percentiles of these variables are compared to national standards that specify the maximum concentration or level of contamination in a drinkingwater supply as established by the U.S. Environmental Protection Agency $(1986 a, b)$. The primary maximum contaminant level standards are health related and are legally enforceable. The secondary maximum contaminant ievel standards apply to esthetic qualities and are recommended guidelines. The primary drinking-water standards include a maximum concentration of $10 \mathrm{mg} / \mathrm{L}$ nitrate (as nitrogen), and the secondary drinking-water standards include maximum concentrations of $500 \mathrm{mg} / \mathrm{L}$ dissolved solids, $250 \mathrm{mg} / \mathrm{L}$ chloride, and $300 \mu \mathrm{g} / \mathrm{L}$ (micrograms per liter) iron.

The ground-water-quality data base for Kentucky includes data from wells and springs sampled only once. The constituent values from those analyses have been used to define water quality at a location. Where multiple analyses were available at a site, the median constituent values were used to define the ground-water quality at the site. The summary shown in figure $2 C$ represents about 94 percent of the 7,563 analyses of ground water in Kentucky. These analyses are stored in the U.S. Geological Survey's National WaterData Storage and Retrieval System (WATSTORE). Those analyses containing concentrations of dissolved solids larger than 10,000 $\mathrm{mg} / \mathrm{L}$ were assumed to have been taken from the extremely mineralized zone of water below the shallow freshwater zone and therefore, were not used in the summary shown in figure $2 C$.

\section{Alluvial Aquifer}

The alluvial aquifer along the Ohio, the Mississippi, the lower Tennessee, and the lower Cumberland River valleys yields large quantities of water and is the most intensively used aquifer in Kentucky (fig. $2 A$, aquifer 1). Numerous public supplies and industrial users withdraw water from shallow wells completed in the alluvium. In Louisville several commercial buildings use ground water for heating and cooling.

The quality of water in the alluvial aquifer generally is good for most uses, and only about 10 percent of the dissolved-solids concentrations are larger than $1,000 \mathrm{mg} / \mathrm{L}$. However, between 25 and 50 percent of the dissolved-solids concentrations (fig. $2 C$, aquifer 1) exceed the national drinking-water standard of $500 \mathrm{mg} / \mathrm{L}$. Water from the alluvial aquifer generally is very hard, with 75 percent of the values of hardness being larger than $210 \mathrm{mg} / \mathrm{L}$. Between 50 and 75 percent of the iron concentrations exceed the national drinking-water standard of $300 \mu \mathrm{g} / \mathrm{L}$. Chloride concentrations normally are smaller than $90 \mathrm{mg} / \mathrm{L}$.

Concentrations of nitrate generally are small, with only 25 percent of the nitrate concentrations being larger than $2.0 \mathrm{mg} / \mathrm{L}$. Examination of the nitrate data indicates that 20 samples from the alluvial aquifer contained nitrate concentrations larger than $11 \mathrm{mg} / \mathrm{L}$, which slightly exceeds the national primary drinking-water standard of $10 \mathrm{mg} / \mathrm{L}$. Further examination of the data showed that 10 of these samples were taken from locations in the six-county metropolitan Louisville area.

Increased concentrations of nitrate may indicate contamination from sources such as septic-tank leach fields and applications of fertilizers. Other investigations have revealed that contamination by oil-field brines, industrial waste and spills, and municipal waste may have locally affected the water quality of the alluvial aquifers (Hopkins, 1963; Davis and Matthews, 1983).

\section{Tertiary and Cretaceous Aquifers}

The Tertiary and Cretaceous aquifers are west of the Tennessee River in Kentucky (fig. $2 A$, aquifer 2). Both aquifers are relatively shallow, and supply water for public, industrial, and domestic purposes. However, these aquifers have not been fully developed as a water supply.

Water from these aquifers is very fresh and soft. Dissolvedsolids concentrations rarely are larger than $250 \mathrm{mg} / \mathrm{L}$ and 75 percent of the values of hardness are smaller than $70 \mathrm{mg} / \mathrm{L}$ (fig. $2 C$. aquifer 2). The median iron concentration in these aquifers is 230 $\mu \mathrm{g} / \mathrm{L}$, but iron concentrations in the Cretaceous aquifer commonly exceed the drinking-water standard. Concentrations of chloride generally are smaller than $30 \mathrm{mg} / \mathrm{L}$ and 75 percent of the nitrate concentrations are smaller than $1.6 \mathrm{mg} / \mathrm{L}$.

\section{Pennsylvanian Aquifer System}

The Pennsylvanian aquifer system is in the coal-mining regions of eastern and west-central Kentucky (fig. $2 A$, aquifers 3 and 4). Wells tapping these aquifers are used for domestic and stock supplies.

Concentrations of dissolved solids in water from the shallow ground-water circulation zone of the Pennsylvanian aquifer system in eastern Kentucky generally do not exceed the drinking-water standard (fig. $2 C$, aquifer 3 ). The water is moderately hard, with only about 25 percent of the hardness values being larger than 120 $\mathrm{mg} / \mathrm{L}$, and generally contains iron in excess of the secondary drinking-water standard. Concentrations of chloride generally are smaller than $110 \mathrm{mg} / \mathrm{L}$, and 90 percent of the nitrate concentrations are smaller than $1.2 \mathrm{mg} / \mathrm{L}$.

Water from the Pennsylvanian aquifer system in west-central Kentucky (fig. $2 C$, aquifer 4) generally contains dissolved-solids concentrations larger than $500 \mathrm{mg} / \mathrm{L}$. Water from these aquifers is hard to very hard-the median hardness is $120 \mathrm{mg} / \mathrm{L}$. Concentrations of iron generally are larger than $300 \mu \mathrm{g} / \mathrm{L}$, and chloride concentrations normally are smaller than $60 \mathrm{mg} / \mathrm{L}$. Concentrations of nitrate are larger in the western Kentucky Pennsylvanian aquifers than in the eastern Kentucky Pennsylvanian aquifers. In the western Kentucky aquifers, 25 percent of the nitrate concentrations are larger than $1.2 \mathrm{mg} / \mathrm{L}$, compared to 10 percent for the eastern Kentucky Pennsylvanian aquifers.

The coal-mining regions of eastern and western Kentucky are being mined and extensively explored for oil and gas reserves. Water samples from deep oil-test wells commonly are briny.

\section{Mississippian Aquifer System}

The karst aquifer system in Mississippian age rocks is in the north-central part of Kentucky (fig. $2 A$, aquifer 5). Water from the Mississippian aquifer system is used as a public supply for several communities.

Water from the Mississippian aquifer system generally is fresh and concentrations of dissolved solids normally do not exceed the drinking-water standard (fig. $2 C$, aquifer 5). Water from this aquifer system is very hard-the median hardness is $226 \mathrm{mg} / \mathrm{L}$. Iron concentrations generally do not exceed the secondary drinkingwater standard $(300 \mu \mathrm{g} / \mathrm{L})$. Concentrations of chloride generally are smaller than $110 \mathrm{mg} / \mathrm{L}$, and 75 percent of the nitrate concentrations are smaller than $2 \mathrm{mg} / \mathrm{L}$.

\section{Ordovician Aquifer System}

The karst Ordovician aquifer system is in the south to northcentral part of Kentucky (fig. $2 A$, aquifer 6 ). The ground water primarily is used for rural domestic and stock purposes.

Water from this aquifer system generally is fresh and dissolved-solids concentrations commonly are larger than $500 \mathrm{mg} / \mathrm{L}$ (fig. $2 C$, aquifer 6). The water is very hard, with 90 percent of the values of hardness exceeding $178 \mathrm{mg} / \mathrm{L}$. Iron concentrations commonly do not exceed the secondary drinking-water standardthe median concentration is $280 \mu \mathrm{g} / \mathrm{L}$. About 25 percent of the chloride concentrations exceed the secondary drinking-water standard. Concentrations of nitrate generally are larger in the Ordovi- 
cian aquifer system than in any other aquifer system in Kentucky; however, only about 10 percent of the nitrate concentrations are larger than $8.0 \mathrm{mg} / \mathrm{L}$.

\section{EFFECTS OF LAND USE ON WATER QUALITY}

Although the general quality of shallow ground water is good for most uses, Kentucky is faced with ground-water degradation problems on a statewide basis. Some incidents have been reported and investigated on a localized basis by the Kentucky Natural Resources and Environmental Protection Cabinet, the U.S. Environmental Protection Agency (EPA), the U.S. Geological Survey, the Kentucky Geological Survey, and other agencies, but the total extent of any degradation is undefined.

\section{Waste Management and Chemical Storage}

Waste management and chemical storage include the following major sources: RCRA-regulated facilities that use a land unit for storage, treatment, or disposal of hazardous waste; NPL listed or nominated abandoned toxic-waste disposal sites; nonhazardous waste-disposal facilities; and underground storage tanks.

As of February 1987, there were 29 RCRA-regulated hazardous waste facilities in Kentucky (fig. $3 A$ ), which are required to monitor ground-water quality (Lori Johnson, Kentucky Natural Resources and Environmental Protection Cabinet, oral commun., 1987). These facilities use landfills, surface impoundments, and waste piles for the storage, treatment, or disposal of hazardous waste. Because of the nature of the waste involved and the possibility of liner failure, these facilities constitute a potential hazard to the quality of ground water. Ground-water contamination has been reported at 12 sites (Lori Johnson, Kentucky Natural Resources and Environmental Protection Cabinet, oral commun., 1986).

Abandoned toxic-waste sites are a serious threat to groundwater quality. In Kentucky, nine such CERCLA sites (fig. 3A) are listed on the NPL (U.S. Environmental Protection Agency, 1986c). The one site shown in Marshall County actually represents two individual sites. One of the sites located in Hardin County, shown as an "other site" in figure $3 \boldsymbol{A}$, has been proposed for addition to the NPL. Four of the CERCLA sites are reported to have created measurable, localized ground-water contamination (Nancy Redgate, U.S. Environmental Protection Agency, oral commun., 1986). Many of the CERCLA and RCRA sites are in the vicinity of populated areas along the Ohio and the Tennessee Rivers.

Nonhazardous waste is defined as solid waste not regulated as a hazardous waste under RCRA. Primarily, landfills and landfarms are used for nonhazardous waste disposal in Kentucky. Figure $3 A$ shows the location of industrial landfills and landfarming sites (designated as "other" sites) and figure $3 C$ shows the location of municipal landfills.

Landfarming is a common practice for the disposal of municipal wastewater treatment sludge. The practice involves the spreading of digested sludge, which is excellent soil additive and fertilizer, on agricultural plots with subsequent mixing of the sludge into the soil layer. Limited data are available to document the potential effect of these sites on the quality of ground water in Kentucky; however, the EPA has issued new sludge-management standards that include ground-water protection standards for landfarming.

Kentucky has more than 100 municipal landfills. Minimal data exist to document the effects, if any, of each landfill on groundwater quality; however, an improperly sited, designed, constructed, or operated facility can allow contaminants to infiltrate the groundwater system. The EPA is reassessing its solid-waste management criteria and guidelines to determine if increased protection of ground water is warranted, particularly for those landfills that receive household hazardous and toxic chemicals.

Underground storage tanks are used in Kentucky to store hazardous and toxic substances and petrochemical products. Con- sequently, they represent a potentially serious threat to ground-water quality if leakage occurs. As a result of this potential threat, the State is implementing a program to regulate such tanks. As of September 1986, the State had inventoried more than 18,000 tanks, with an estimated 25 percent of them possibly leaking contaminants (A.L. Smothers, Kentucky Natural Resources and Environmental Protection Cabinet, oral commun., 1986).

\section{Mineral Development}

Coal mining in Kentucky, which started in the early 1800's, affects the area of the Pennsylvanian aquifers. Many ground-water problems have occurred in these regions of Kentucky. The reasons for these problems include improper mining and reclamation techniques, and improperly constructed and abandoned wells and exploratory holes (Kentucky Natural Resources and Environmental Protection Cabinet, 1986). Sloane and Warner (1984) reported that dewatering of an aquifer can affect the quality of ground water by exposing materials containing pyrite to oxygen. When water percolates through the oxidized material, the resulting chemical reactions can make available for transport increased concentrations of iron and other heavy metals.

Surface mining also can affect the quality of ground water. Collier and others $(1964 ; 1970)$ reported that water in spoil material is more highly mineralized than water from the bedrock aquifers, and its composition is dependent on the chemical composition of the spoil material. Water in spoil material has infiltrated the groundwater system and increased sulfate concentrations in bedrock aquifers. Where mining is or has been intense, such as in the Evarts, Cranks Creek, and the Clover Fork areas of Harlan County, ground water is considerably mineralized (Kentucky Natural Resources and Environmental Protection Cabinet, 1986).

Oil and gas development in the Pennsylvanian and Mississippian aquifers also affects the quality of ground water. Oil was first discovered in Kentucky in 1819 and most wells today are stripper wells, which produce both brine and oil. Brine brought to the surface by stripper wells is injected, under EPA regulation, into a suitable formation or discharged under Kentucky Natural Resources and Environmental Protection Cabinet regulation, to streams, sinkholes, or evaporation pits. However, brines injected into improperly constructed wells, or illegally discharged to streams, sinkholes, or evaporation pits can infiltrate the shallow ground-water system. The extent of such contamination has not been defined.

By far the most serious cause of ground-water contamination problems associated with oil and gas wells is the improper casing and plugging of exploration and production wells. Many old holes have deteriorated plugs, and other holes have been left unplugged. Such holes serve as connections between fresh and briny aquifers (Kentucky Natural Resources and Environmental Protection Cabinet, 1986).

\section{Urbanization}

The effect of urbanization on the quality of ground water within Kentucky is not well documented. Ground-water quality can be affected by leaking septic tanks and sewers, as well as inadequately sited and designed leach fields, increased densities of waste disposal and underground storage facilities, and the covering of recharge areas by roads and buildings. The fluctuations of groundwater quality and water levels in a well in urban Jefferson County, Kentucky, are shown in figure 4 . Analysis of these data did not conclusively show that urbanization was the cause of the changes. However, increased concentrations of dissolved solids, chloride, nitrate, or bacteria are indications of ground-water contamination by septic-tank leach fields. Also, in northern Jefferson County, at least 15 percent of the septic systems have failed to function as wastedisposal systems, but only limited data are available to document 
the effects of septic seepage on ground-water quality (U.S. Environmental Protection Agency, 1983a).

Perhaps the best example of the effects of urbanization on ground-water quality occurs in Bowling Green, Kentucky. The city, located in an environmentally vulnerable karst plain, has a history of ground-water contamination by point and nonpoint sources. To date, storm-water runoff has contributed oil, grease, metals, and bacteria to the ground water; gasoline leakage has resulted in fumes forming in caverns and moving upward into at least 30 homes, 2 elementary schools, a business, and a church; and point-source discharges to sinkholes have created significant problems (Kentucky Natural Resources and Environmental Protection Cabinet, 1986).

\section{Potential for WATER-Quality Changes}

The largest potential for changes in the quality of Kentucky's ground water exists in karst areas. About 50 percent of Kentucky is karst terrane, and ground-water recharge in karst areas occurs, in most instances, as direct flow from the surface through solution openings, such as sinkholes or swallets, in the limestone. Underground drainage can consolidate to a few well-developed conduits, as indicated by well and spring yields ranging from gallons to thousands of gallons per minute. Where caves are present, the water table may occur below the level of streambeds, and water may be lost to the subsurface. In such instances, underground streams that are created have flow and water-quality characteristics somewhat similar to surface streams, particularly in their potential to assimilate organic wastes.

Owing to the availability of open conduits to the ground-water system, aquifers in karst terrane are extremely vulnerable to contamination. Surface flows, such as contaminated storm-water runoff from urban and agricultural areas, can directly discharge to the ground-water system. It is not uncommon for sinkholes in urban areas to be converted to drainage wells for storm-water runoff control and disposal. The EPA has not developed regulatory standards for drainage wells (Class $\mathrm{V}$ injection wells). Therefore, the wells are unregulated by this agency and the Kentucky Natural Resources and Environmental Protection Cabinet, unless a specific well can be demonstrated to be adversely affecting public health.

When a contaminant enters a karst conduit, it can reach a discharge point, either a spring, well, or surface stream, in a short time. Ground-water velocities have been observed to range from 1.5 to 23 miles per day (Mull and Lyverse, 1984, p. 24). Throughout Kentucky, springs and wells in karst terrane are contaminated by bacteria, nutrients, metals, and a variety of organics. Consequently, proper land-use planning, waste management, chemical-product management, and storm-water management are critical to continued reliance on ground water as a potable water supply in the karst terrane of Kentucky.

Except for a limited number of localized watersheds, such as in Elizabethtown in Hardin County (Mull and Lyverse, 1984), the hydrogeology of the karst aquifers of Kentucky have not been studied in detail. Many of these areas are experiencing both longterm and emergency-incident ground-water contamination problems. For example, in 1982, at Buttermilk Spring in Meade County, a serious outbreak of viral hepatitis-A was reported. This outbreak resulted in 1 fatality and 110 cases of reported illness (Kentucky Natural Resources and Environmental Protection Cabinet, 1984). Water from many wells in this karst area also contained levels of fecal and total coliform greater than the highest desirable concentrations recommended by the State ( 0 and 4 colonies per 100 milliliters, respectively) for private water supplies (Russell Barnett, Kentucky Natural Resources and Environmental Protection Cabinet, written commun., 1987). The source of the contamination is still undetermined and the recharge area providing water to this spring has not been mapped.
Perhaps just as significant is the unknown number of leaking underground storage tanks that contain hazardous and toxic substances and petrochemical products. Kentucky has initiated a program to inventory all existing tanks and to determine which tanks may be leaking contaminants to the ground water, requiring corrective action.

\section{GROUND-WATER-QUALITY MANAGEMENT}

In November 1984, the Kentucky Water Management Plan was adopted, calling for the development of a ground-water management program. In August 1985, a Ground-Water Advisory Council was appointed to oversee the development and implementation of this program. The council consists of representatives from each of the State agencies responsible for the management and protection of ground water, as well as the State and Federal Geological Surveys.

Five State agencies are responsible for enactment of the 10 State statutes that address ground water in Kentucky:

Division of Water is the primary agency responsible for developing and implementing a comprehensive ground-water management program. The Division's Ground-Water Branch is responsible for developing a statewide ground-water protection strategy, maintaining a ground-water data base, administering a water-well drillers certification program, and other protection efforts.

Division of Waste Management's Solid and Hazardous Waste Management Program is responsible for regulating waste treatment, storage, and disposal facilities under RCRA and the State solid-waste statute. Ground-water monitoring is required at some solid and all hazardous waste land treatment, storage, and disposal facilities. The Division cooperates with the EPA in their efforts to implement the provisions of CERCLA, and has initiated a program to regulate underground storage tanks.

Department for Health Services is responsible for monitoring the quality of private ground-water supplies and regulating the use of individual waste disposal systems, such as septic tanks.

Division of Oil and Gas administers a program designed to protect freshwater during drilling, plugging, and waste-injection operations (Class II injection wells) associated with the oil and gas industry. The Division is seeking primacy from the EPA for administering the Federal regulatory program for Class II injection wells.

Department of Surface Mining Reclamation and Enforcement is responsible for regulating the mining industry, including monitoring the effects of surface and underground mining on the groundwater resource.

In addition, the Kentucky Geological Survey, in cooperaton with the U.S. Geological Survey, collects and compiles groundwater-level and water-quality qdata for the Commonwealth.

\section{SELECTED REFERENCES}

Collier, C.R., and others, 1964, Influences of strip mining on the hydrologic environment of parts of Beaver Creek basin, Kentucky, 1955-59: U.S. Geological Survey Professional Paper 427-B, 85 p.

Collier, C.R., Pickering, R.J., and Musser, J.J., 1970, Influences of strip mining on the hydrologic environment of parts of Beaver Creek basin, Kentucky, 1955-66: U.S. Geological Survey Professional Paper 427-C, $77 \mathrm{p}$.

Davis, R.W., and Matthews, E.W., 1983, Chloroform contamination in part of the alluvial aquifer, southwest Louisville, Kentucky: U.S. Geological Survey Water-Supply Paper 2202, 25 p.

Faust, R.J., Banfieid, G.R., and Willinger, G.A., 1980, A compilation of ground-water quality data for Kentucky: U.S. Geological Survey OpenFile Report 80-685, 963 p.

Hopkins, H.T., 1963, The effect of oilfield brines on the potable ground water in the upper Big Pitman Creek basin, Kentucky: Kentucky Geological Survey, Series 10, Report of Investigation 4, 36 p. 
Kentucky Natural Resources and Environmental Protection Cabinet, 1984, Kentucky water management plan, Proposal to Governor M.L. Collins: p. 53-59.

1986, 1986 Kentucky report to Congress on water quality: $192 \mathrm{p}$.

Mull, D.S., and Lyverse, M.L., 1984, Ground-water hydrology of the Elizabethtown area, Kentucky: U.S. Geological Survey WaterResources Investigations Report 84-4057, 59 p.

Sloane, Patrick, and Warner, Richard, 1984, A case study of groundwater impact caused by underground mining: Symposium on Surface Mining Hydrology, Sedimentology, and Reclamation, 1984, Lexington, University of Kentucky, Proceedings, p. 113-126.

Sprinkle, C. L., Davis, R.W., and Mull, D.S., 1983, Evaluation of groundwater quality data from Kentucky: U.S. Geological Survey WaterResources Investigations Report 83-4240, 65 p.

U.S. Environmental Protection Agency, 1982, Mill Creek area, Jefferson County, Kentucky wastewater facilities, Environmental Impact Statement: U.S. Environmental Protection Agency, Report EPA 904/9-82-097, $151 \mathrm{p}$.

1983a, North Jefferson County, Kentucky wastewater facilities, Draft Environmental Impact Statement: U.S. Environmental Protection Agency, Report EPA 904/9-83-115, 255 p. 1983b, Ground-water management in the southeastern United States: U.S. Environmental Protection Agency, Report EPA 600/2-83-090, $533 \mathrm{p}$.

1986a, Maximum contaminant levels (subpart B of part 141, National interim primary drinking-water regulations): U.S. Code of Federal Regulations, Title 40, Parts 100 to 149 , revised as of July 1,1986 , p. $524-528$.

1986b, Secondary maximum contaminant levels (section 143.3 of part 143, National secondary drinking-water regulations): U.S. Code of Federal Regulations, Title 40, Parts 100 to 149, revised as of July 1,1986 , p. $587-590$.

1986c, Amendment to National Oil and Hazardous Substances Contingency Plan; national priorities list, final rule and proposed rule: Federal register, v. 51, no. 111, June 10, 1986, p. 21053-21112.

U.S. Geological Survey, 1985, National water summary 1984-Hydrologic events, selected water-quality trends, and ground-water resources: U.S. Geological Survey Water-Supply Paper 2275, 467 p.

U.S. Tennessee Valley Authority, 1984, Ground-water situation assessment of the Tennessee Valley region: Technical Report Series, TVA/ONRED/AWR-84/12, v. II, p. 5-1 to 5-44.

Prepared by James L. Kiesler, Lloyd H. Woosley, Jr., and Robert W. Davis

FOR ADDITIONAL INFORMATION: District Chief, U.S. Geological Survey, 2301 Bradley Avenue, Louisville, Ky 40217 


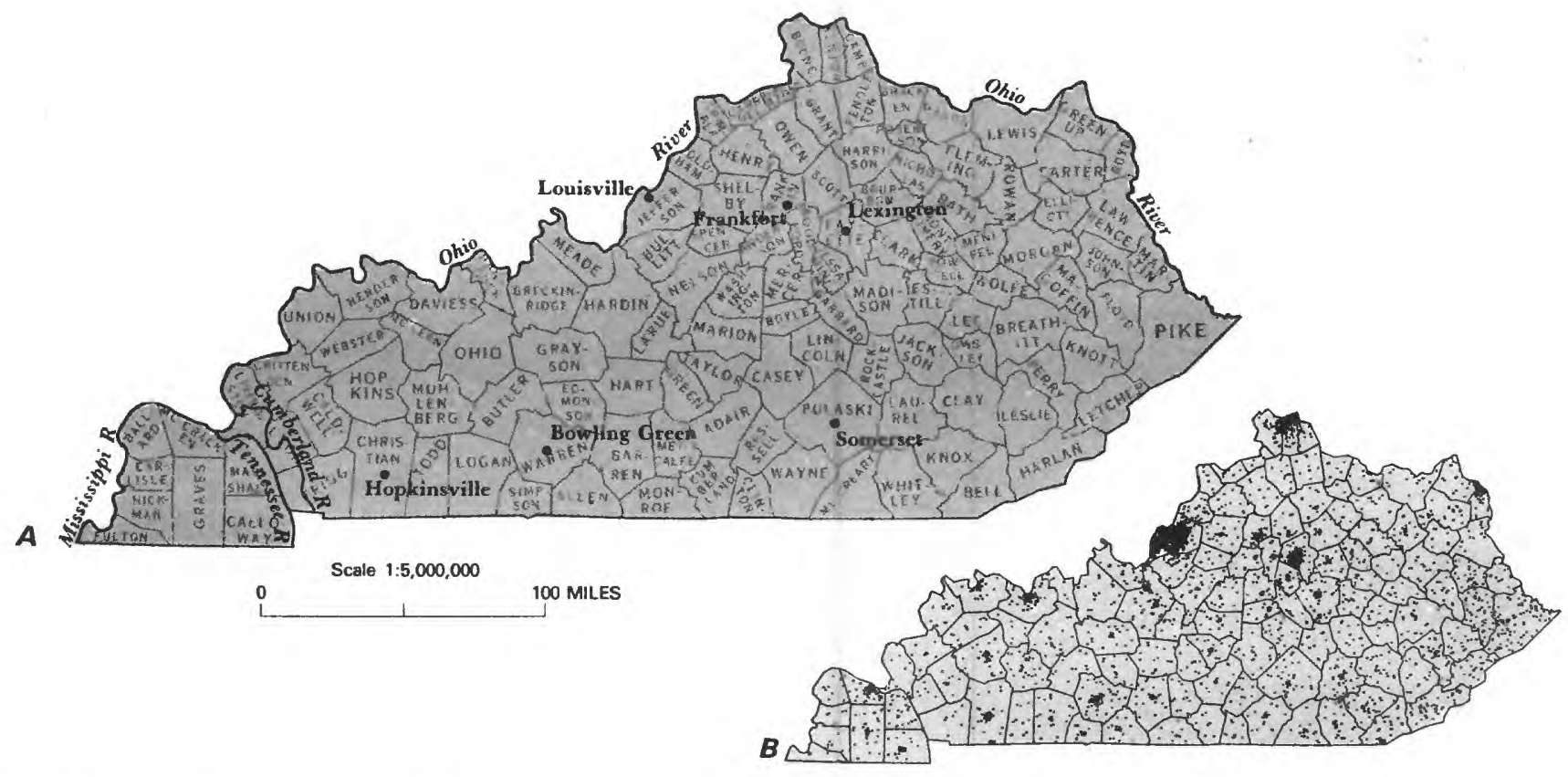

Figure 1. Selected geographic features and 1985 population distribution in Kentucky. A, Counties, selected cities, and major drainages. B, Population distribution, 1985; each dot on the map represents 1,000 people. (Source: B. Data from U.S. Bureau of the Census 1980 decennial files, adjusted to the 1985 U.S. Bureau of the Census data for county populations.I 


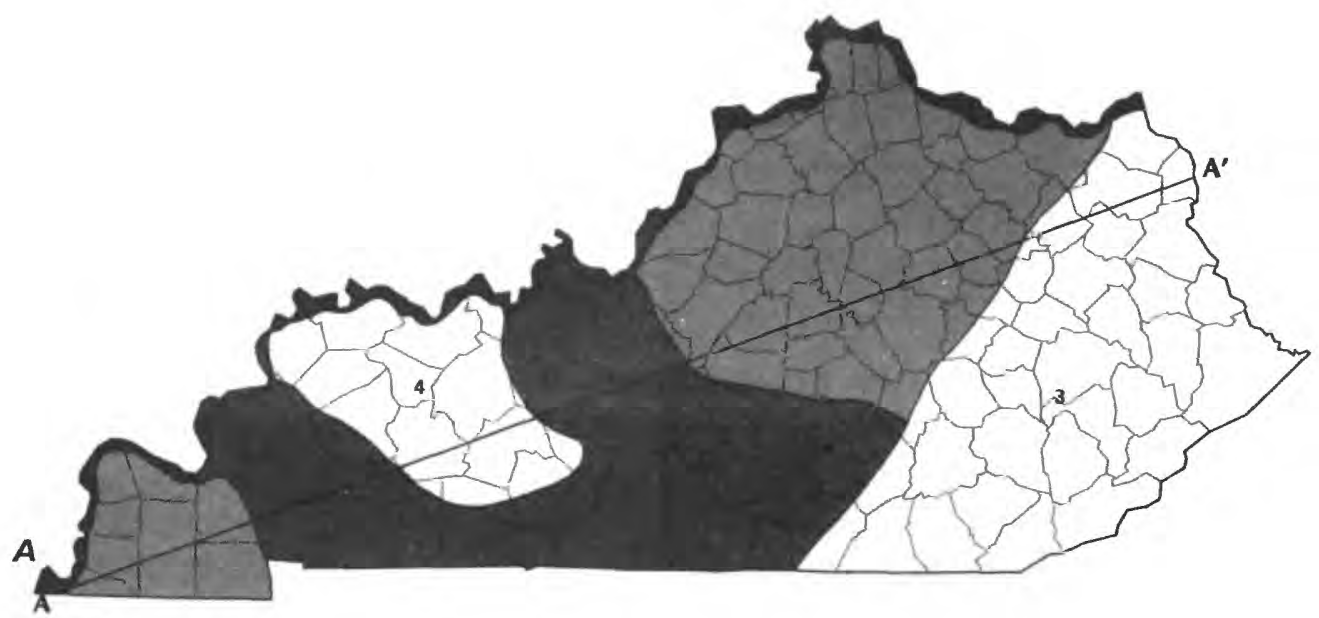

PRINCIPAL AQUIFER - Numeral is

aquifer number in figure $2 \mathrm{C}$

Alluvial (1)

Tertiary and Cretaceous aquifers (2)

Pennsylvanian aquifer system $(3,4)$

Eastern Kentucky Pennsylvanian aquifers (3)

Western Kentucky Pennsylvanian aquifers (4)

Mississippian aquifer systen (5)

Ordovician aquifer system (6)

A-A $\mathbf{A}^{\prime}$ Trace of hydrogeologic section - Horizontal scale of section 50 percent of map scale

\section{C}

\section{WATER-QUALITY DATA}

Percentile - Percentage of analyses equal to or less than indicated values -90th

-75 th
-50 th

- 25th

Natlonel drinking-water standerds

- Maximum permissible contaminant level (primary)

- - Maximum recommended contaminant level (secondary)

Reporting limit

Minimum reporting level with

analytical method used

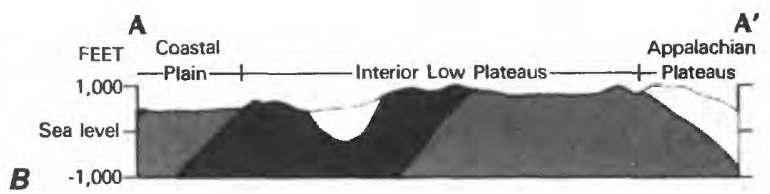

NUMBER OF ANALYSES

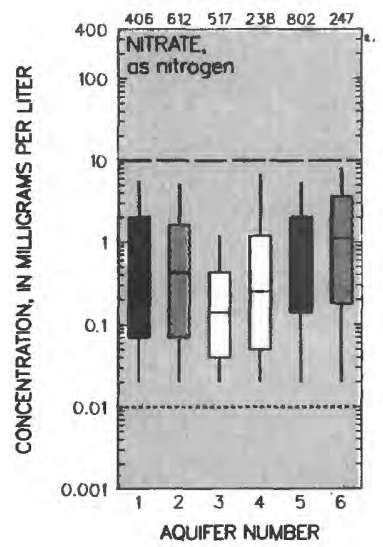

NUMBER OF ANALYSES
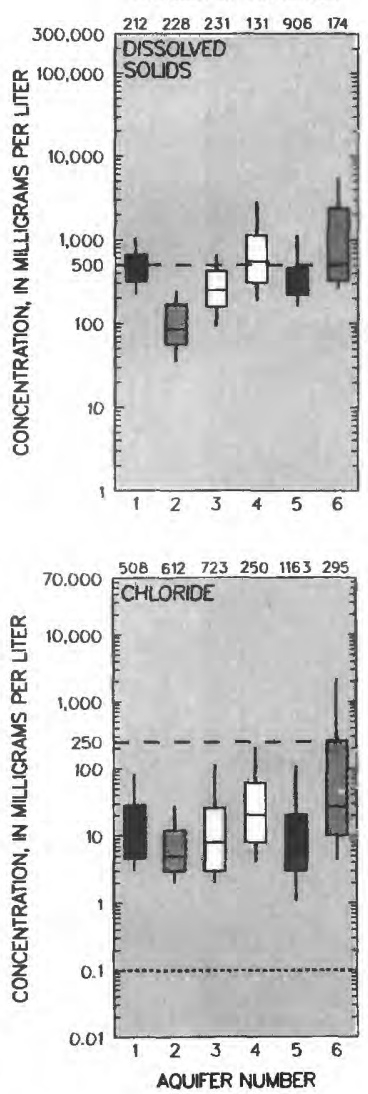

NUMBER OF ANALYSES
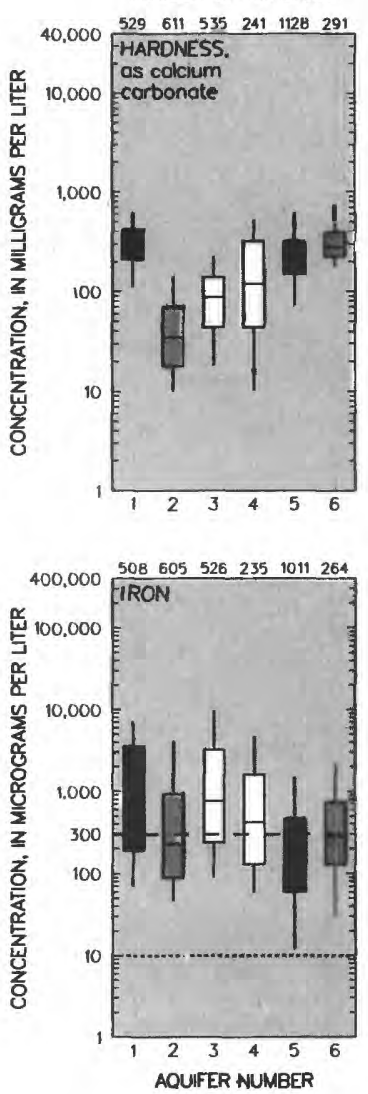

Figure 2. Principal aquifers and related water-quality data in Kentucky. $A$, Principal aquifers. $B$, Generalized hydrogeologic section. $C$, Selected waterquality constituents and properties, as of 1930-86. (Sources: A, B. U.S. Geological Survey, 1985. C, Analyses compiled from U.S. Geological Survey files; national drinking-water standards from U.S. Environmental Protection Agency, 1986a,b.) 
WASTE SITE - Darker symbol indicates site where contaminants were detected in ground water. Numeral indicates more than one site at

same general location

2 - Cercla (Superfund)

- rCRa

- Other - Contamination status is unknown
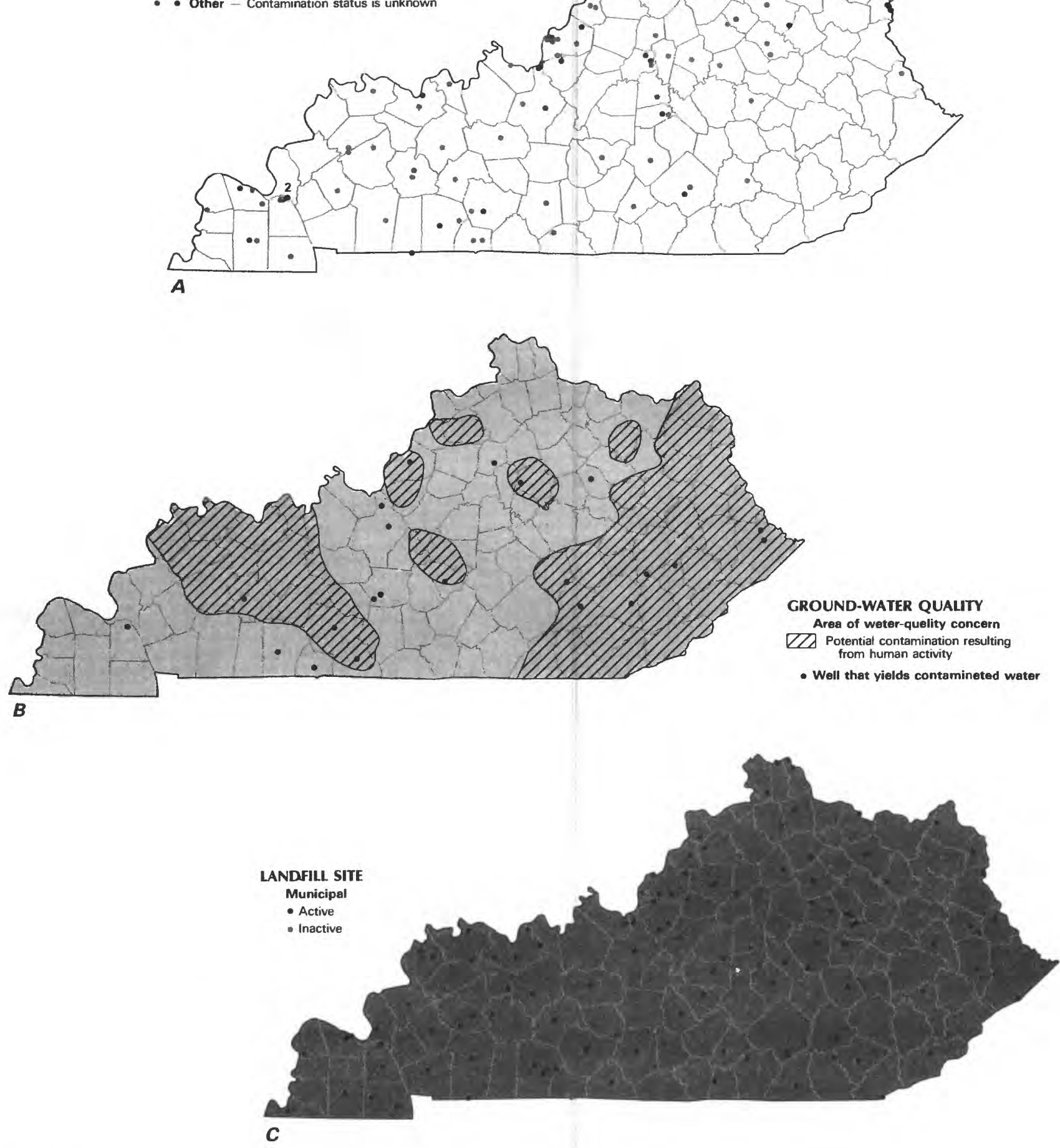

Figure 3. Selected waste sites and ground-water-quality information in Kentucky. A, Comprehensive Response, Compensation, and Liability Act (CERCLA) sites; Resource Conservation and Recovery Act (RCRA) sites; and other selected waste sites, as of February 1987. B, Areas of potential contamination and distribution of wells that yield contaminated water, as of July 1986. C, Municipal landfills, as of July 1986. (Sources: $A, B, C, K e n t u c k y$ Natural Resources and Environmental Protection Cabinet files.) 

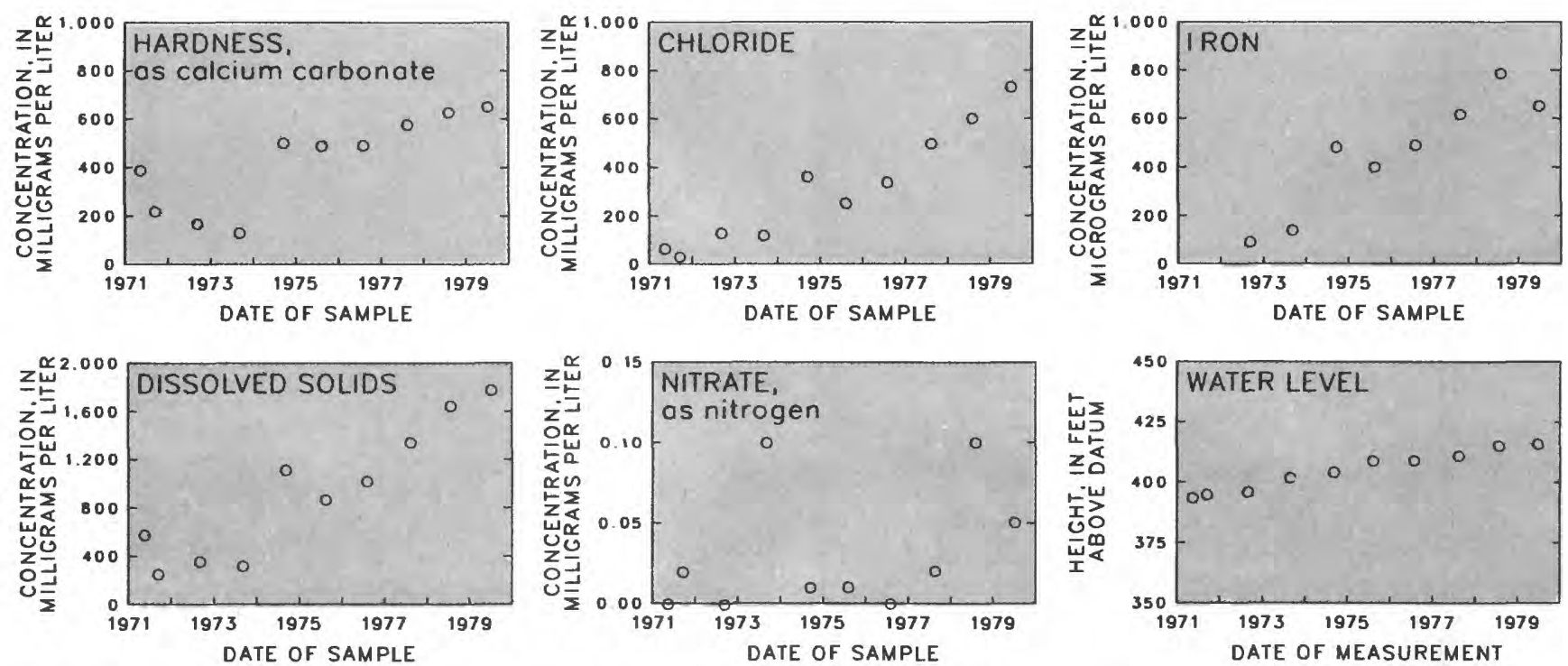

Figure 4. Fluctuations in ground-water quality and water level in the alluvial aquifer at Louisville. (Source: U.S. Geological Survey files.) 